\title{
An Evolving Shared Concept of Development Cooperation: Perspectives on the 2030 Agenda
}

\author{
Milindo Chakrabarti and Sachin Chaturvedi
}

\subsection{INTRODUCTION}

With a collective commitment to the Sustainable Development Goals (SDGs), the worlds of development cooperation, in general, and development finance, in particular, are keenly looking for new and innovative sources of financing for effective and timely outcomes. It is with this backdrop that the growing emphasis and discussions on inclusion-as encapsulated in the idea of "inclusive development"-are to be viewed. This commitment to the SDGs also brings a shift from quantitative to qualitative aspects of development goals along with cross-domain and cross-border connections.

This would require greater cohesion at the global level and breaking out of silos and narrow national growth strategies (e.g. the present debate on climate change mitigation strategy, or the re-emergence of protectionist trade policies being pursued by individual nations, triggering a potential trade war). Eventually, this may entail the recognition of appropriate institutional mechanisms in a spirit of collective action, as the implementation of the SDGs may require a set of global public goods (GPGs) for the effective delivery of quality goods and services, which somehow were met through a narrow focus on quantitative accomplishments in the time of the Millennium Development Goals.

M. Chakrabarti $(\bowtie) \cdot S$. Chaturvedi

Research and Information System for Developing Countries (RIS), New Delhi, India e-mail: milindo.chakrabarti@ris.org.in

S. Chaturvedi

e-mail: sachin@ris.org.in; dgoffice@ris.org.in

(C) The Author(s) 2021 
The challenge to be settled during the coming days would be to identify an effective global institutional structure that could be proposed by the members of the G20. This structure to help implement the action plans for the 2030 Agenda for Sustainable Development may be designed by the G20 in close collaboration with non-G20 members. Although sustainable development is a universal developmental goal, there is a long history of "development cooperation" at work. However, as of today, three distinct models of "development cooperation" can be identified. They are (i) the official development assistance (ODA)-based model of North-South cooperation (NSC), led by the Organisation for Economic Co-operation and Development (OECD)/Development Assistance Committee, (ii) the South-led solidarity and sharing-based model of South-South cooperation (SSC), and (iii) the newly evolving model of triangular cooperation $(\operatorname{TrC})$, which involves joining hands between two entities to provide development support to a third country. The exact identity of the entities that would provide development support has yet to be agreed upon. Furthermore, both NSC and SSC are based on a set of stated principles-at times to the extent of contradicting one another-and they are always posited as being complementary to each other. Any such stated set of driving principles for $\operatorname{TrC}$ has yet to emerge. Given these ground-level variations across the different models of development cooperation, it is pertinent to raise a fundamental question as to how development partnerships can be institutionalised around SDG 17, which calls for "Partnerships for the goals". Are the existing institutional models for development cooperation-NSC and SSC—sufficient to help achieve the other 16 goals? In case they are not, is the emerging model of $\operatorname{TrC}$ capable of filling the institutional vacuum? If $\operatorname{TrC}$ is also not expected to deliver, what alternative institutional framework could the G20 propose?

The present chapter is an endeavour to identify a new set of global institutional structures to effectively facilitate the achievement of some SDGs. The next section develops the analytical framework that helps conceptualise the three premises driving the process of development cooperation. The subsequent section advocates the usefulness of using a multi-modality approach in development cooperation, articulated in the literature as "development compact" (Chaturvedi 2016). Following that, the next section purports that most, if not all, of the SDGs create GPGs, in the sense that the achievement of the targets are neither rivalled in consumption nor do they exclude anyone from accruing the benefits of these targets. The spirit of "no one is left behind" aptly captures the GPG characteristics of the outcomes of achieving the targets. A few case studies were written to find the extent to which these premises were maintained in organising the provision of GPGs through the creation of new forms of global institutional structures. Issues as diverse as health care (GAVI, the Vaccine Alliance, involving SDGs 3, 4, and 17), peacekeeping (SDGs 16 and 17), and energy (International Solar Alliance, ISA, involving SDGs 7, 13, and 17) have been taken up. The case studies indicate that such institutional frameworks are often effective in creating access to resources, and thereby contribute to the creation of some specific types of GPGs. Broadly, 
it has been observed that successful collective actions were organised around issues that centred on a lack of access to particular resources, and that such actions involved multiple actors, including non-state ones.

\subsection{Analytical Framework}

The basis for this framework rests on contextualising cooperation against the background of the fundamental requirements for development. It is based on integrating three conceptual premises that underscore the global quest for sustainable development and coming up with an effective but new institutional mechanism that can create GPGs. These conceptual premises are based on a primary construct that development, or the lack of it, is characterised by the degree of access to resources. The underlying objective of "leaving no one behind" as a given target for the achievements of the SDGs is very much centred around the intention of providing better access to resources for all. The provision of GPGs is tantamount to lowering the access barriers for those who are lagging behind.

The resources that are used by any human being may be divided into four distinct components: natural resources-those supplied by nature; economic resources-those which are man-made and include produced resources, technology, and knowledge; political resources ${ }^{1}$ - the power to negotiate the access regime for the first two types of resources; and social resources-social networks based on faith, belief systems, and kinships. The last two types of resources may be grouped under institutional resources. It is interesting to note that access to any of these resources is not independent of access to the rest of the resources. Access to natural resources is contingent upon access to economic, social, and political resources. The long history of colonialism may be cited as an attestation of the argument. Simultaneously, access to political resources is also conditioned by access to economic resources. The reverse is also tue, simultaneously. The variations in the degree of access to resources are observed at all levels-local, subnational, national, regional, and global-and thus explain the existence of developmental disparities at all of these levels. Given this primary construct, we would argue that development cooperation and the quest for sustainable development may be framed using the following three premises. We shall observe later that the idea of a development compact can also be meaningfully inferred to emerge from this theoretical framework. The premises are:

1. Access to resources and capability: The world is divided between those who enjoy greater access to value-added resources and those who have lower degrees of such access. The former is described as "developed" and the latter "developing". Such distinctions exist among "states" at an aggregative level and also among communities within a "state" at a disaggregated level ${ }^{2}$ (Chakrabarti 2018). 
2. Role of prevailing institutional architecture in facilitating access: Access to resources and the capability to add value to them are determined by the prevailing institutional architecture at the global, regional, and local levels, which, in turn, is indicative of one's access to political and social resources. The institutional architecture determines the rules of the game to be followed in the distribution of, access to, withdrawal of, management of, exclusion from, alienation of, and the making of alterations to resources. Whereas access refers to "the right to enter a defined physical property", withdrawal implies "the right to obtain the 'products' of a resource". Management takes care of "the right to regulate internal use patterns and transform the resource by making improvements", whereas alteration refers to "the right to change the set of goods and services provided by a resource". Finally, exclusion is "the right to determine who will have an access right, and how that right may be transferred", and alienation refers to "the right to sell or lease some or all rights". The rights beyond access play their respective roles in determining the capability of a community or a nation to add value to the resources they have access to (Schlager and Ostrom 1992, pp. 249-262).

3. Focus on stakeholders: There exist multiple groups of stakeholdersoften with conflicting interests-keen on enjoying the aforesaid rights to resources and the capability to add value to them. Designing an appropriate institutional structure involves creating opportunities for collective action and balancing such interests across stakeholders to ensure the optimal utilisation of the resource in question. The collective action also involves costs to the participating stakeholders. They lose because of the institutional restrictions put on their behaviour in terms of access, withdrawal, management, alteration, exclusion, and alienation vis-à-vis the resource in question. On the other hand, collective inaction is often preferable, as it removes such restrictions vis-à-vis the behaviour of an individual, who can then enjoy complete behavioural freedom. However, there are situations when the cost of collective action becomes less than that of collective inaction. This premise is substantiated by the recent emergence of a global consensus towards the adoption of the SDGs. With the realisation that collective inaction would increase the vulnerability of human beings in terms of their social, economic, and ecological existence, all the countries across the world agreed to sign on the dotted lines and engage in effective collective action, even at the expense of curtailing their "national sovereignty" to a considerable degree.

\subsection{The Development Compact}

It may be pertinent to explore at this juncture as to how ODA-as extended by the members of the OECD and development cooperation-as practised within the ambit of SSC, would identify possible meeting points, and how theoretical and institutional frameworks would help delineate elements for 
different modalities (Chakrabarti 2016). The requirement of resources and the development of an appropriate access regime to such resources as well as their appropriate sources vis-à-vis domestic spending, concessional international funding, and/or private investments will depend on such institutional frameworks that are entwined with effective and operational models. Development cooperation may essentially be looked at as an effort to enhance access to resources and capacity for increased value addition for communities that are lagging behind, compared to others enjoying a larger domain of access.

All such activities involve invoking a better access protocol and can be classified under five heads of the "development compact": capacitybuilding, trade and investment, development finance, technology transfer, and grants. Capacity-building activities contribute to enhanced access to economic resources through human resource development, and thereby to increased capacity for enhanced value addition. Trade and investment, on the other hand, facilitate greater access to resources such as goods and services, along with access to markets beyond domestic boundaries. Technology transfer is akin to access to economic resources, which facilitates value addition. Development finance and grants facilitate access to financial resources, albeit indirectly, and provide access to economic resources.

Needless to say, even though we differentiate between these five modalities, they may not remain mutually exclusive while being used. Just as the access framework for the apparently distinct four resources we identified are intertwined, the different modalities under the development compact are also interlinked with one another. They may be used in several possible permutations and combinations to facilitate the process of "access" for those who have been lagging behind. Such possible variations in their relative importance when deciding on the appropriate access regime create space for multi-stakeholder governance systems for development. Compared to the greater emphasis on grants and loans in the OECD schema, the development compact - through its multi-modality approach, which facilitates access to political and social resources by augmenting the human-capital base of a country-appears to effectively handle the whole of the access system mentioned above. Increased opportunities for trade broaden access to social networks in the form of strengthening people-to-people connections. Opening up market access also helps to enhance social access. Increased cooperation in a horizontal space also contributes to collective efforts in enhancing the level of political access at the global level. Engaging actors beyond the state-including civil society organisations, academia, people's representatives, traders, policymakers, among others-helps in formulating a multi-stakeholder governance mechanism for development, or sustainable development to be specific. In this process, these actors also facilitate the creation of positive externalities, which are enjoyed by all the participants. This reduces the cost of collective action involving different stakeholders, who often might have had conflicting interests in a particular resource governance regime in a prior situation of collective inaction. 
A few comments linking GPGs with the SDGs are in order. The present chapter argues that almost all of the SDGs are linked to the provision of public goods and have a global imperative- they may be termed as facilitating GPGs. Public goods tend to be undersupplied and are required to be supplied in larger quantities on a global scale. However, on a cautionary note, it may be said that the issues of concern in achieving the 17 SDGs do not necessarily relate directly to the provision of GPGs alone. The SDGs-which are related to poverty, hunger, health and well-being, education, gender equity, sanitation, employment and economic growth, industrial activities, and reduced inequality-directly qualify to be considered as the creation of GPGs, as they involve the provision of global resources in order to achieve them so that no one is left behind. SDG 17, in the form of partnerships for the goals, clearly articulates the GPG aspect of the SDGs. However, apparently, some of the SDGs cannot be considered as providing GPGs. Rather, they are characteristically more akin to protecting global commons. The SDGs linked to the protection of global commons are those relating to life on land and below water as well as to climate action. Conceptually, whereas a public good suffers from the fate of the underprovision of resources to create them, commons are problematic because they tend to be overconsumed, as existing institutional mechanisms are not efficient enough to prevent their overconsumption, and consequently they suffer from the tendency of being overused. However, it requires the provision of considerable resources-economic, political, and social-and the facilitation of access to them by humanity to develop the necessary incentive-disincentive mechanisms that encourage the protection of global commons from the present state of overconsumption. The provision of such resources is akin to that required for the creation of GPGs.

\subsection{A Few Case Studies}

We share a few case studies that underscore the relevance of the conceptual framework elaborated in the section above. Whereas the first case study looks at the experiences of the workings of GAVI, the Vaccine Alliance (GAVI) in proving a GPG, the second one considers the case of ISA, which is being jointly promoted by India and France in an effort to simultaneously provide a GPG and protect a global common-the global climate. The final one relates to India's experiences in peacekeeping under United Nations (UN) supervision. The cases follow a common pattern in their elaborations. We identify the three premises already elaborated in the earlier sections, namely: increasing access as the focus of action, the institutional mechanism that was crafted to increase access, and the engagement of stakeholders in a polycentric set-up to institutionalise "increased" access to the resource in question. It is also noted that they all are related to one or more of the SDGs. 


\subsubsection{GAVI, the Vaccine Alliance}

GAVI, which came into being in 2000, holds the special promise of health for all that we have been longing for. It covers SDG 3 (access to good health and well-being), SDG 6 (access to clean water and sanitation), and SDG 17 ("Partnerships for the goals").

\subsubsection{Objectives and Principles}

Why was there a need for GAVI? The institutional structures prevailing before GAVI had failed on several parameters, leading to the dire need for another intervention. The World Health Organization's (WHO) Expanded Programme on Immunization (EPI) barely registered any change in global immunisation rates. Later, the Universal Childhood Immunization campaign of WHO and the United Nations Children's Fund (UNICEF)-though showing commendable performance in terms of coverage and results-soon lost momentum after it began focussing on other priorities.

There were several reasons supporting the demand and necessity to come up with an institutional change to ensure better access to health-related resources.

First, a state of development can be measured by the degree of access to value-added resources. Access to the resources and processes that are required to reduce child mortality is necessary for sustainable development. A healthy population is the first prerequisite for having such capabilities. By exploring the synergies between public and private partners - which include governments of both developed and developing countries, civil society organisations, independent individuals, research and technical health institutes, in addition to the founder, the Bill \& Melinda Gates Foundation-GAVI hopes to provide the people with opportunities to realise reduced levels of child mortality.

The second important component for access to resources in terms of sound institutional architecture has also been considered. GAVI tries to make these resources available through its participatory and collective approach of taking along most of the stakeholders in a process with a polycentric design. This effort by GAVI to supply the desired changes hinges on a unique approach that combines funding and partnership.

\subsubsection{Funding}

The Vaccine Alliance is funded through direct contributions ( 77 per cent) and innovative finance (23 per cent). Direct contributions include grants and agreements from donor governments, foundations, corporations, and organisations - in other words, they include support from both the public and private sectors. Innovative financing mechanisms include the International Finance Facility for Immunisation (IFFIm), the Pneumococcal Advance Market Commitment (AMC), the GAVI Matching Fund, and the loan buydown facility. They are also financed by public and private sources. In addition, the innovation ecosystem helps countries modernise their immunisation 
delivery systems by sourcing proven high-impact technologies and "infusing" them with resources and expertise to take them to scale. GAVI-supported countries are also required to contribute a portion of the cost of purchasing their vaccines. The co-financing policy helps them to facilitate programme sustainability after GAVI's financial support ends.

\subsubsection{Partnership}

As stated above, in terms of providing financial resources, GAVI's partners include both governments and private-sector entities: 79 per cent of GAVI's funding is from governments committed to GAVI's mission of saving children's lives, whereas 21 per cent of contributions come from the private sector, which is emerging as a prominent component of GAVI's diversified financing strategy. Care should be taken to note that governments and private-sector entities contribute simultaneously to innovative financing mechanisms and also engage in direct contributions to the GAVI fund.

WHO has partnered to regulate vaccines and support country introductions, thereby strengthening immunisation coverage and data quality; UNICEF is in partnership to procure vaccines and support countries in maintaining their cold chains, improving access, and collecting data; the World Bank helps pioneer innovative finance mechanisms such as the IFFIm and the AMC; the Bill \& Melinda Gates Foundation and other private-sector partners provide funding and expertise; implementing country governments join hands to identify their immunisation needs as well as to co-finance and implement vaccine programmes; civil society organisations help ensure that vaccines reach every child; vaccine manufacturers guarantee vaccine quality, supply, and affordability for developing countries; donor-country governments make long-term funding commitments; private-sector partners contribute resources, expertise, and innovation to help achieve GAVI's mission; research agencies help GAVI generate the evidence base and communicate the value of vaccines.

\subsubsection{The Institutional Structure of GAVI}

Health system strengthening (HSS) is the format by which GAVI addresses the bottlenecks in the health systems of the recipient countries. GAVI holds that strong health systems are essential in expanding and sustaining immunisation coverage. For instance, it employs a health workforce; improves the supply, distribution, and maintenance of vaccines; and works on the organisation and management of the procedures in order to strengthen the systems. There were 69 countries that had been approved for support in such a manner by the end of April 2017 (GAVI, the Vaccine Alliance [GAVI], n.d.-a).

GAVI works in a unique, circular way. The country receiving support is the starting point of the whole process. The implementing country puts forth new proposals and annual progress reports of its performance. These reports are reviewed together by the GAVI Secretariat, Vaccine Alliance partners, and the Independent Review Committee, which then give their recommendations to the GAVI Board on how the respective country delivery can be improved. 
These recommendations are implemented through the provision of vaccines and HSS support by GAVI to the implementing country. The implementing country again submits the proposals and annual progress reports, which lead to another cycle.

A full country evaluation is the tool through which gaps in the systems of the implementing countries are identified, leading to further actions towards improvement. Huge financial flows committed by GAVI to the countries ensure the easing of financial constraints in the proposed plans.

Thus, GAVI replaces the "institutions of control" with the "institutions of collective action" and propounds the idea that the cost of coming together (collective action) is much less than the cost of working alone or not collaborating (collective inaction). It shows how a potentially effective model can be developed that benefits all of its stakeholders if they consciously decide to participate in collective action.

It can also be gauged through GAVI's resource mobilisation model, which is a form of $\mathrm{TrC}$ involving the co-financing efforts of the respective countries, aided by a strong donor base and market-shaping strategies. The promising initiatives in this direction have been IFFIm, which ensures the long-term predictability of financing by efficiently leveraging capital markets to shift funds to meet country demand; AMC, which accelerates the manufacturing and delivery of vaccines; and the GAVI Matching Fund, which maximises the value of giving for corporations as well as their customers and employees.

GAVI's co-financing policy works by identifying three phases of graduation of country ownership and the steps to sustainability. Countries are in the initial self-financing phase when per capita gross national income (GNI) is less than $\$ 1045$, which leads to the second phase, when GNI is between $\$ 1045$ and $\$ 1580$ and consists of countries in the preparatory transition phase. Finally, the third phase is when per capita GNI is more than $\$ 1580$ and countries are called to be in the accelerated transition phase. The first phase demands that countries pay $\$ 0.20$ per dose, whereas the second phase asks for increases in co-payments of 15 per cent per year, and the third phase requires a steady increase in payments in order to reach sustainability after five years. Thus, the purpose of co-financing policy is to enhance ownership and put countries on a trajectory towards financial sustainability in preparation of phasing out GAVI support in accordance with increases in GNI per capita.

India is in the third phase of co-financing policy, whereby it began transitioning away from GAVI support in 2017, and thus expects to begin fully self-financing all of its vaccine programmes by 2021. GAVI is committed to assist India with up to $\$ 345$ million during this period to strengthen its health systems as well as its supply of vaccines against pneumonia and rotavirus. Up until 29 March 2019, around \$290 million was sanctioned out of the committed amount; around \$179 million (61.72 per cent of the committed amount for the period between 2017 and 2023) has already been disbursed.

The Government of India is already prioritising reaching every child with vaccines with its new Mission Indradhanush initiative. With its HSS methods, 
GAVI can push this cause even further and help India achieve its set targets. India is in immense need of such support given the fact that it is home to 4 million under-immunised children, which accounts for about a fifth of all GAVI-supported countries.

GAVI and its partners will provide targeted support to help India's immunisation system identify and reach children who are not receiving vaccines, including exploring how India's vast number of polio workers can support uptake of other routine vaccines, such as the 5 -in- 1 pentavalent vaccine and these new vaccines. (GAVI 2016)

[Sixty per cent] of all GAVI-procured vaccines are manufactured in India. Through the partnership, GAVI and the Government of India plan to work more closely together to help create a more sustainable global and domestic vaccine manufacturing base within India. This will be crucial to ensuring sufficient vaccine supplies are available for the 27 million children born in India every year, and children living in all 72 other GAVI-supported countries. (GAVI 2016)

India has committed \$9 million to GAVI for the cycle between 2016 and 2020 , which amounts to 0.11 per cent of the total commitments (GAVI, n.d.-b).

The GAVI model is an apparently successful display of putting the development priorities of developing countries at the centre (Brooks et al. 2017; Bustreo et al. 2015; Lee et al. 2013). It is a demand-driven model in which countries choose their own issues and decide where GAVI's support needs to be applied. GAVI provides completely untied aid, and up to 97 per cent of GAVI support is based on multi-year commitments. Also, there is active participation by civil society, specifically for scaling-up immunisation equity and coverage.

As per the latest information available at the GAVI website, against a target of immunising 300 million children by 2020, GAVI so far has achieved the immunisation of 198 million children, compared to having immunised 66 million children in 2018; 4.3 million future deaths have been averted through this effort, as compared to 1.7 million in 2018 . The under-five mortality rate has dropped from 64 per 1000 in 2015 to 59 per 1000 in 2018, against a 2020 target of 58 per 1000 . Future disability-adjusted life years averted currently stand at 203 million compared to 80 million in 2018 against a 2020 target of 250 million. What is further encouraging is the fact that the vaccination process was carried out in all of the countries that were no longer receiving GAVI support. Independent academic studies also support some of the findings. It has been observed that expanded access to, and free provision of, post-exposure prophylaxis through GAVI would prevent an additional 489,000 deaths between 2020 and 2035. Under this switch to efficient intradermal post-exposure prophylaxis regimens, total projected vaccine needs remain similar (about 73 million vials). Yet, 17.4 million more people are 
vaccinated, making this an extremely cost-effective method, with costs of $\$ 635$ per death being averted and $\$ 33$ per disability-adjusted life years averted (WHO Rabies Modelling Consortium 2019). A case study of GAVI's 15-year engagement with a vaccine against diphtheria, tetanus, pertussis, hepatitis $\mathrm{B}$, and haemophilus influenzae type $\mathrm{b}$ (pentavalent) provides evidence of the benefits and potential risks of trying to influence markets (Malhame et al. 2019). As a recognition of GAVI's services, it was presented with the 2019 Lasker-Bloomberg Public Service Award.

As argued earlier, polycentric institutions represent a suitable combination of institutions at levels that take care of operational and governance issues. Such an approach has been initiated by GAVI, as the interests of its stakeholders intersect and overlap on the common goal of providing a given health service globally. The combination of long-term commitments in the form of technical expertise of the development community with the business knowhow of the private sector-along with contributions of resources (financial and/or human) from other stakeholders according to their ability-is arranged to help achieve the long-term goal of immunisation with self-sufficiency.

It is not that GAVI has had a smooth road. There have been problems identified with even this institutional structure. GAVI has been questioned on several grounds in the Full Country Evaluation Reports by the independent evaluators as to: how demonstration projects could have been better designed to maximise learning for the national introduction of vaccines; how complex the nature of HSS procedures is; how there are a number of deficiencies in the design of GAVI HSS grants; how the oversized administrative and management burdens of GAVI grants and processes have further strained the limited programme capacity of EPI introduced by WHO long back; and how overly optimistic the application and implementation timelines are, to name a few. But having said that, the reason why GAVI still succeeds is the fact that it incorporates these suggestions into the following cycle of HSS for the country.

The case study presented on GAVI clearly indicates that a new institutional structure that cuts through hierarchical structures, with the nation states at the centre, can also be quite effective in ensuring greater access to resources and the capacity to add value to them. Examples in terms of the growth of the internet, success of peacekeeping operations, etc., also contribute meaningfully to arguments in favour of creating such multi-stakeholder institutions. A structured understanding of GAVI is given in Table 5.1.

\subsubsection{International Solar Alliance}

ISA is also a very effective example of efforts at developing a polycentric institution in providing access to energy to communities that are largely energy-deficient. It is an initiative to bring in effective collective action in facilitating increased access to energy; consequently, the adoption of SDGs also adds credence to the three premises elaborated upon earlier. ISA was jointly launched by India and France on 30 November 2015 at the UN Climate 
Table 5.1 Features of GAVI

\begin{tabular}{|c|c|}
\hline Elements of theoretical framework & Features of GAVI \\
\hline \multirow[t]{3}{*}{$\begin{array}{l}\text { Access to resources, capabilities, and } \\
\text { modalities }\end{array}$} & $\begin{array}{l}\text { - Pathways for sustainable, affordable health } \\
\text { services and access to clean water and } \\
\text { sanitation facilities }\end{array}$ \\
\hline & $\begin{array}{l}\text { - Reductions in the costs of finance and } \\
\text { technology }\end{array}$ \\
\hline & $\begin{array}{l}\text { - Reduction in the levels of child mortality } \\
\text { and consequent capacity-building, leading } \\
\text { to enhancement in the quality of human } \\
\text { capital }\end{array}$ \\
\hline \multirow[t]{3}{*}{ Institutional architecture } & $\begin{array}{l}\text { - Access to sound institutional architecture, } \\
\text { which GAVI tries to make available } \\
\text { through its participatory and collective } \\
\text { approach of taking along most of the } \\
\text { stakeholders in the process }\end{array}$ \\
\hline & $\begin{array}{l}\text { To ensure efficient collective action, } \\
\text { multi-stakeholder institutional structures } \\
\text { are being created }\end{array}$ \\
\hline & $\begin{array}{l}\text { - Finances to be supported by multilateral, } \\
\text { public, and philanthropic stakeholders and } \\
\text { contributions from them }\end{array}$ \\
\hline \multirow[t]{3}{*}{ Focus on stakeholder } & $\begin{array}{l}\text { - Aspires to involve multiplicity of } \\
\text { stakeholders }\end{array}$ \\
\hline & $\begin{array}{l}\text { - Potential stakeholders include } \\
\text { governments, bilateral and multilateral } \\
\text { organisations, industry, corporate } \\
\text { enterprises, and philanthropic entities }\end{array}$ \\
\hline & $\begin{array}{l}\text { - Seeks cooperation with other stakeholders } \\
\text { involved in this area/domain }\end{array}$ \\
\hline
\end{tabular}

Source Authors

Change Conference in Paris (COP 21). It is conceived to establish a common platform for cooperation among solar resource-rich countries (i.e. Suryaputras or sunshine countries) that are located fully or partially between the Tropics of Cancer and Capricorn to harness solar energy. In this context, sunshine countries share common challenges and opportunities as far as sustainable energy resources are concerned. ISA is intended to create opportunities for greater collaboration in technology, research and development, and capacity-building (Cernuschi et al. 2018). Part of ISA is still in its infancy, but the initiative merits attention also at the level of planning. The ISA Framework Agreement was opened for signatures during COP 22 at Marrakesh on 15 November 2016. There are 121 potential countries that are considered to be rich in solar power. Of them, 86 countries have signed and 68 countries have further ratified the ISA Framework Agreement as of 8 September 2020: 30 of them belong to the category of least-developed countries, while 37 are Small Island 
Developing States. ISA partners include multilateral financial institutions such as the Asian Development Bank, the African Development Bank, the New Development Bank, the Asian Infrastructure and Investment Bank, the European Investment Bank, and the World Bank. Specialised international agencies such as the International Energy Agency (IEA), the International Renewable Energy Agency (IRENA), the Green Climate Fund, the Climate Parliament, and the Regions of Climate Action have also partnered with ISA. The United Nations Development Programme (UNDP) has also chipped in as a partner in this endeavour. The notable ones among the corporate partners are a number of energy-linked public-sector enterprises from India, in addition to private-sector entities such as Soft Bank in Japan and CLP in Hong Kong.

ISA is now an inter-governmental body registered with the UN under Article 102 of the UN Charter and headquartered in Gurugram, India.

\subsubsection{Objectives and Principles}

Some of the collective aspirations of this common platform are: reducing the costs of finance and technology for the immediate deployment of competitive solar generation; paving the way for future solar generation, storage, and good technologies for countries' individual needs; and increasing the utilisation and promotion of solar energy and solar applications in its member countries (Press Information Bureau [PIB] 2016e). Ghosh and Chawla (2016) call it a mission to take it from the lab to the streets. In this process, ISA also intends to create direct and indirect employment opportunities and increase economic activities in member countries (PIB 2016b). ISA aims to be a $\$ 1$ trillion opportunity, and the Global Solar Council (GSC) ${ }^{3}$ has committed to creating 25 million jobs in the solar space among ISA countries (PIB 2016a).

Its five-point plan of action includes:

- Rural and decentralised applications: Most Alliance member countries are agrarian economies. This programme aims to improve yields and economic benefits by providing reliable, affordable solar applications that are suited to needs and accessible to all farmers in various fields.

- Access to affordable finance: The financial cost is currently the major obstacle to the deployment of solar technologies, despite rapid technological progress. The countries taking part in the programme work on drawing up common principles for legislative and regulatory frameworks, and on risk-reduction instruments aimed at enhancing their chances of accessing finance.

- Island and village solar mini-grids: Islands and non-interconnected communities are among those most interested in renewables, and solar in particular. This programme aims to develop and replicate commercial models, adopt common standards, and launch calls for tenders for the installation of mini-grids. 
- Rooftop installations: Thanks to its ability to generate small quantities of energy at multiple feed-in points, rooftop solar panels can produce decentralised energy, thus limiting the costs of upgrading grids and pooling electrical production variations across a large number of installations. This programme aims to lift barriers to its development.

- Solar e-mobility: Solar e-mobility technologies (including roads, vehicles, and scooters) are seeing very rapid development. This programme seeks to develop these applications and promote their deployment, including through energy storage, and to harmonise practices across the countries taking part in the programme.

\subsubsection{The Institutional Structure of ISA}

As mentioned earlier, ISA aims at involving a multiplicity of stakeholders. Apart from governments, stakeholders include bilateral and multilateral organisations, industry, corporate enterprises, and others. For instance, ISA is working in close cooperation with UNDP for the creation of complementary linkages; strategic cooperation in programmatic and technical expertise; the establishment of knowledge-management systems; and the strengthening of ISA's institutional structure (PIB 2016c). In addition, ISA is collaborating with the World Bank to promote solar energy globally by developing financial instruments, roadmaps to mobilise financing (including concessional financing), as well as technical assistance and knowledge transfer (PIB 2016d).

India has also committed to supporting ISA by hosting its Secretariat at the National Institute of Solar Energy campus in Gurgaon, India, for an initial period of five years. Thereafter, it is expected to generate its own resources and become self-financing (PIB 2016b).

Two programmes of ISA-Affordable Finance at Scale and Scaling Solar Applications for Agricultural Use-were launched in April 2016 and are intended to serve the primary interests of farming communities (PIB 2016f). Another such initiative is the Terrawatt Initiative, which is a global non-profit initiative that seeks to gather all relevant stakeholders through partnerships, memorandums of understanding, informal agreements, and workshops (Terrawatt Initiative 2016). Such programmes target the necessities of solarrich countries.

Potential linkages to ISA are to be explored with the initiative Solar Guidelines India, which is under the Indo-German Energy Programme. This initiative is to act as the central information database of India's Ministry for New and Renewable Energy and the Solar Energy Corporation of India (SECI) for all stakeholders in the solar sector in India. It has been conceived in order to enable investment and stimulate the development of the India's solar sector (Solar Guidelines 2016).

As far as institutional mechanisms and governance structure are concerned, ISA is still in the development phase. It has established an assembly and a Secretariat. The second assembly was held in Delhi on 31 October 2019, 
whereas the Secretariat has been operating from Gurugram, India, since 2016. Among the recent initiatives taken up by ISA is the ISA Solar Cooling Initiative (also known as I-SCI), in collaboration with the University of Birmingham in the UK. The initiative aims to help member countries develop solar-energy-linked cold chains and cooling systems for agricultural use.

\subsubsection{Contributions}

In January 2018, India committed to setting up a \$350 million solar development fund. In addition, nine companies and banks have agreed to develop and finance various solar projects, which include a \$1 billion partnership corpus of the National Thermal Power Corporation and CLP India to the ISA. In addition, India has provided $\$ 62$ million for the establishment of the ISA Secretariat. Heads of state and government from 23 member countries attended a day-long summit on 11 March 2018 in New Delhi to formally inaugurate the platform for the mass deployment of solar energy, especially in developing countries. India has already provided assistance worth $\$ 143$ million for 13 solar projects that have been completed or are being implemented across the world. Continuing with this co-operative effort, India will be providing assistance to the tune of $\$ 1.4$ billion for 27 new projects in 15 developing countries. These solar projects are in Bangladesh, Mali, Seychelles, Tanzania, Mali, Rwanda, Nigeria, Ghana, and Guinea. During the summit, France also committed $€ 700$ million to ISA.

It may be recalled that on 30 June 2016, the Alliance entered into an understanding with the World Bank to accelerate the mobilisation of finance for solar energy. The bank will have a major role in mobilising more than \$1000 billion in the investments that will be needed by 2030 to meet ISA's goals of generating 1 TW of affordable solar energy.

As part of its plans to provide proactive leadership in the diffusion of solar energy, India also committed to provide 500 training slots (in solar technology) every year to ISA member countries.

The other recurring expenditures of ISA are intended to be met through membership fees; contributions from bilateral and multilateral agencies; other appropriate institutions; and also from interest earned from the corpus fund (PIB 2016b). As ISA requires massive investment for affordable solar energy by 2030 , contributions from multiple stakeholders are an essential feature of the ISA financing mechanism.

The contributions from India to the development of ISA so far have taken several forms.

- The government of India will contribute \$27 million to ISA for creating the corpus, building infrastructure, and paying recurring expenditures over a five-year duration from 2016-2017 to 2020-2021. 
- SECI and the Indian Renewable Energy Development Agency have contributed $\$ 1$ million each to create the ISA corpus fund.

- India's Ministry of External Affairs, through its Development Partnership Administration programme, has set aside \$1.5-\$2 billion as a line of credit facility to undertake solar projects in those African countries that have signed and ratified the ISA Framework Agreement.

- India is also committed to providing 500 training slots for member countries and starting a solar tech mission to lead research and development. So far, two such training programmes on Solar Energy for Master Trainers from ISA member countries have been organised under the Indian Technical and Economic Cooperation Programme, which involves more than 60 participants.

The French Agency for Development committed $€ 700$ million for solar projects by 2022 , bringing its total commitment to $€ 1$ billion since the creation of ISA. A structured understanding of ISA is given in Table 5.2.

Table 5.2 Features of the International Solar Alliance

\begin{tabular}{|c|c|}
\hline Elements of theoretical framework & Features of ISA \\
\hline $\begin{array}{l}\text { Access to resources, capabilities, and } \\
\text { modalities }\end{array}$ & $\begin{array}{l}\text { - Pathway for sustainable, affordable, and } \\
\text { clean energy, and mitigating climate } \\
\text { change concerns } \\
\text { - Reductions in the costs of finance and } \\
\text { technology } \\
\text { - Capacity-building to enhance the quality } \\
\text { of human capital }\end{array}$ \\
\hline Institutional architecture & $\begin{array}{l}\text { - To ensure efficient collective action, } \\
\text { multi-stakeholder institutional structures } \\
\text { are being created } \\
\text { - Proposal for an assembly, a council, and a } \\
\text { Secretariat } \\
\text { - Finances to be supported through } \\
\text { membership fees, interest earned, and } \\
\text { contributions from various stakeholders }\end{array}$ \\
\hline Focus on stakeholder & $\begin{array}{l}\text { - Aspires to involve a multiplicity of } \\
\text { stakeholders } \\
\text { - Potential stakeholders include } \\
\text { governments, bilateral and multilateral } \\
\text { organisations, industry, and corporate } \\
\text { enterprises } \\
\text { - Seeks cooperation with other stakeholders } \\
\text { involved in this area/domain }\end{array}$ \\
\hline
\end{tabular}

Source Authors 


\subsubsection{UN Peacekeeping}

UN Peacekeeping (UNPK) can be cited as another endorsement of the access-institution-polycentricity model expounded in this chapter. In the selfhelp-based prevailing international system, the disastrous consequences of the two world wars provided valuable insights on the need for international peace and security. This was further necessitated by conflicts arising due to power struggles within and among states. However, there was no collective international mechanism to maintain peace in conflict zones before the UN initiated peacekeeping efforts in 1948 to maintain international peace and security. As a consequence of the two world wars, this state of affairs was felt to have changed, and collective action of a universal character began. Taking into account the contributions of UNPK, it was awarded the Nobel Peace Prize in 1988.

\subsubsection{Objectives and Principles}

Peace enables smooth access to resources and adds value that is conducive for development. As such, UN drew attention to the need for collective action through the means of peacekeeping, which is a strategy to maintain and preserve peace in conflict zones as well as to assist in implementing agreements achieved by stakeholders. Moreover, peace enables the conditions for the realisation of the SDGs in the contemporary context. In addition, the cost of collective action for peacekeeping is less than the cost of collective inaction.

UN peacekeepers are sent to diverse regions that range from regions where civil-war conditions prevail to places where there are no agreements, or agreements with negligible scope for commitment from the warring groups as far as the settlement of conflict is concerned. So far, 71 such missions have been initiated-13 of them are currently in operation (as of September 2020). In many cases, they are also sent to regions where constitutional authority either does not exist or exists with limited authority. In such diverse conditions, peacekeepers are required to keep hostile factions apart at a safe distance, safeguard humanitarian relief operations, monitor human rights violations, assist in mine clearance, monitor state boundaries or borders, provide police support to the citizens, assist in rebuilding logistical infrastructure such as roads, railways, and bridges, and support electoral processes.

UNPK involves global partnerships as well as collective action of a universal character, which is reflected in the composition of its various peacekeeping missions. UNPK missions consist of personnel from many countries in order to create conditions for lasting peace in the conflict zones. Due to the transformational nature of the international security environment, UNPK has evolved from a simple model of peacekeeping - involving only the military-into a complex, multi-dimensional peacekeeping model consisting of the military, police, and civilians working together for sustainable peace.

In addition, UNPK is guided by three basic principles: (i) consent of the parties, (ii) impartiality, and (iii) non-use of force, except in self-defence and defence of the mandate. 


\subsubsection{Institutional Structure}

UNPK functions under a normative framework provided by the UN Charter, the UN Security Council (UNSC) mandates, international human rights laws, and international humanitarian laws. Though UNPK does not find explicit mention in the UN Charter, its legal basis is derived from the Charter itself. As mentioned in Chapter VI (Pacific Settlement of Disputes), Chapter VII (Action with Respect to the Peace, Breaches of the Peace and Acts of Aggression), and Chapter VII (Regional Arrangements) of the UN Charter, various arrangements provide the legal and institutional foundations for UNPK operations. Moreover, UNPK takes into account various dimensions mandated by international human rights laws and international humanitarian laws. In accordance with these provisions, UNPK operations are mandated by the UNSC in order to fulfil its primary authorised responsibility - as per the UN Charterto maintain global peace and security. The UNSC consists of five permanent members - the victor nations of the Second World War-which hold veto power. Other members of the UNSC are the 10 non-permanent members, which are elected for two-year terms by the UN General Assembly (UNGA).

Once the mandate is formulated, the hierarchical authority, command, and control structure of UNPK is transferred to a multinational institution. At the headquarters level, the Under-Secretary-General (USG) for Peacekeeping Operations monitors all UNPK operations. The Head of Mission (HOM), who coordinates activities in the field, exercises operational authority in the field and reports to the Secretary-General (SG) through the USG for Peacekeeping Operations.

The existing and mandated institutional structures of UNPK in any particular country involve distinct layers of governance-operational, collective choice, and constitutional. Whereas the ground-level operations are coordinated and managed by operational-choice-level institutions staffed by personnel both from within and outside of the country, the collective-choicelevel institutions maintain communication liaisons within the constitutionalchoice-level structure.

\subsubsection{Contributions}

As UNPK is a collective action, its financing is the collective responsibility of all members of the UN, in accordance with Article 17 (Chapter IV) of the UN Charter. Accordingly, the UNGA has framed some general principles for financing UNPK operations through Resolution 55/235 of December 2000. Moreover, these provisions are also updated, as per requirements of various peacekeeping missions. As of 1 September 2019, there were 109,736 people serving in UN peacekeeping operations $(85,674$ uniformed people from 120 countries, 12,932 civilians, and 1230 volunteers) representing 122 countries. European nations contribute nearly 7000 units to this total. Pakistan, India, and Bangladesh are among the largest individual contributors, with more than 5000 units each. African nations contributed nearly half the total-more than 44,000 units. Approved resources for the period from 1 July 2018 until 30 
June 2019 is about $\$ 6.69$ billion. The annual budget of UNPK missions is 0.5 per cent of the global military budget, signifying the cost-effectiveness of the missions to ensure peace in disturbed regions.

UNPK keeps evolving according to emerging necessities. An Agenda for Peace-written by then-SG of the UN, Boutros Boutros-Ghali (Ghali 1992)as well as the Report of the Panel on United Nations Peace Operations (Brahimi 2000) and the Report of the High-level Independent Panel on Peace Operations (United Nations 2015) reflect these realities and indicate a transformation in the approaches of UNPK. In this context, one remarkable aspect is that the overwhelming number of conflict zones where UNPK missions have taken place or are ongoing lie in the Global South. Moreover, most of the countries that contribute personnel to UNPK missions are from the South. Though it is being authorised by the UNSC and receiving financial contributions from every UN Member State, the actual implementation of missions on the ground relies on credible contributions from the South. This also points to the need for a greater role and engagement of the South in the decision-making processes of UNPK as well as the involvement of non-state actors, which requires both institutional and political changes. A structured understanding of UNPK is given in Table 5.3.

Table 5.3 Features of UNPK

\begin{tabular}{ll}
\hline Elements of theoretical framework & Features of UNPK \\
\hline $\begin{array}{l}\text { Access to resources, capabilities, and } \\
\text { modalities }\end{array}$ & $\begin{array}{l}\text { Pathway for peace and prosperity of } \\
\text { conflict-ridden nations and consequent } \\
\text { enhancement in access to resources } \\
\text { - Capacity-building to enhance the quality } \\
\text { of human capital } \\
\text { - Financing is the collective responsibility } \\
\text { of all members of the UN } \\
\text { - A multi-stakeholder institutional structure } \\
\text { involving the UN and local government. } \\
\text { The HOM, who coordinates activities in } \\
\text { the field, exercises operational authority } \\
\text { in the field and reports to the SG/USG } \\
\text { - Aspires to involve a multiplicity of } \\
\text { stakeholders } \\
\text { - UNPK has evolved from a simple model } \\
\text { of peacekeeping-involving only the } \\
\text { military-into a complex, } \\
\text { multi-dimensional peacekeeping model } \\
\text { consisting of the military, police, and } \\
\text { civilians working together for sustainable } \\
\text { peace }\end{array}$ \\
\hline
\end{tabular}

Source Authors 


\subsection{By Way of Conclusion}

The year 2015 marked a watershed in the annals of human history. All 193 countries in the world ratified the adoption of the 2030 Agenda for Sustainable Development and its 17 Sustainable Development Goals on 26 September during the UNGA Summit in New York. The goals are aimed at making a world where no one is left behind and built around the 5 P's-people, planet, prosperity, peace, and partnership - to set off an ambitious agenda that aims to tackle poverty, climate change, and inequality for all people in all countries. Sustained efforts have been called for to ensure that the goals are achieved by 2030. A list of 169 targets and 230 indicators has been prepared to guide each country towards achieving these goals within a given time frame.

The achievement of such ambitious goals would involve providing access to a host of resources to large segments of the global population. Such an access regime would require considerable resources-physical, financial, human, and, on top of those, institutional-in order to be created. In order to move forward on this track, member nations must explore ways and means to move in a collective manner and ensure greater inclusion. In the process, more GPGs would probably be created. As we found in the cases described above, it is possible to create access to desired resources for larger segments of humanity, even with the crafting of innovative institutional mechanisms that are not purely market-driven. Naidu et al. (2019) argue that

[e]conomics does have its universals, of course, such as market-based incentives, clear property rights, contract enforcement, macroeconomic stability, and prudential regulation. These higher-order principles are associated with efficiency and are generally presumed to be conducive to superior economic performance. But these principles are compatible with an almost infinite variety of institutional arrangements with each arrangement producing a different distributional outcome and a different contribution to overall prosperity.

Polycentric institutions, as opposed to monocentric ones, can provide effective solutions for many of the vexing problems identified by the SDGs. The call to respect plurality will be difficult to ignore.

\section{Notes}

1. Access to such resources facilitates increased access to power-sharing, for example: leadership, governance, etc.

2. One such example is the process of colonisation, wherein some resource-poor colonisers could develop at the expense of the access to the resources of their colonies. In the process, the colonies became "developing" or "underdeveloped".

3. The GSC is an association of leading national and regional solar associations from both established and emerging markets in order to unify the solar power sector at an international level, share best practices, and accelerate global market developments. The GSC can complement ISA in its mission. 


\section{REFERENCES}

Brahimi, L. (2000). Report of the panel on United Nations peace operations (A/55/305-S/2000/809). https://undocs.org/A/55/305.

Brooks, A., Habiman, D., \& Huckerby, G. (2017). Making the leap into the next generation: A commentary on how Gavi, the Vaccine Alliance is supporting countries' supply chain transformations in 2016-2020. Vaccine, 35, 2110-2114.

Bustreo, F., Okwo-Bele, J. M., \& Kamara, L. (2015). World Health Organization perspectives on the contribution of the Global Alliance for Vaccines and Immunization on reducing child mortality. Archives of Disease in Childhood, 100(Issue Suppl 1), s34-s37.

Cernuschi, T., Gaglione, S., \& Bozzani, F. (2018). Challenges to sustainable immunization systems in Gavi transitioning countries. Vaccine, 36(45), 6858-6866.

Chakrabarti, M. (2016). Development compact-The cornerstone of India's development cooperation: An “externalities" perspective (Policy Brief No. 8). New Delhi: Forum for Indian Development Cooperation.

Chakrabarti, M. (2018). Lexicon and syntax: Sustainable Development Goals-An access perspective. Development Cooperation Review, 1(8), 28-31.

Chaturvedi, S. (2016). The logic of sharing: Indian approach to South-South cooperation. Delhi: Cambridge University Press.

GAVI (GAVI, the Vaccine Alliance). (2016, January 6). Historic partnership between Gavi and India to save millions of lives. https://www.gavi.org/news/media-room/ historic-partnership-between-gavi-and-india-save-millions-lives.

GAVI. (n.d.-a). Countries approved for support. https://www.gavi.org/programmesimpact/our-impact/countries-approved-support.

GAVI. (n.d.-b). Donor profiles. https://www.gavi.org/investing/funding/donor-con tributions-pledges/annual-contributions-and-proceeds/.

Ghali, B. B. (1992). An agenda for peace: Preventive diplomacy, peacemaking and peace-keeping (A/47/277-S/24111). Report of the Secretary-General. https:// www.un.org/ruleoflaw/files/A_47_277.pdf.

Ghosh, A., \& Chawla, K. (2016, August 26). Can the international solar alliance change the game? The Hindu. https://www.thehindu.com/opinion/columns/Canthe-international-solar-alliance-change-the-game/article14589187.ece.

Lee, L. A., Franzel, L., Atwell, J., Datta, S. D., Friberg, I. K., Goldie, S. J., et al. (2013). The estimated mortality impact of vaccinations forecast to be administered during 2011-2020 in 73 countries supported by the GAVI Alliance. Vaccine, 31(Supplement 2), B61-B72.

Malhame, M., Baker, E., Gandhi, G., Jones, A., Kalpaxis, P., Iqbal, R., et al. (2019). Shaping markets to benefit global health-A 15-year history and lessons learned from the pentavalent vaccine market. Vaccine: $X, 2,100033$.

Naidu, S., Rodrik, D., \& Zucman, G. (2019, February 15). Economics after neoliberalism. Boston Review. https://bostonreview.net/forum/suresh-naidu-dani-rodrikgabriel-zucman-economics-after-neoliberalism.

PIB (Press Information Bureau). (2016a, April 22). ISA trillion dollar opportunity to serve humanity. Press Release. http://pib.nic.in/newsite/PrintRelease.aspx?relid= 139091.

PIB. (2016b). International Solar Alliance (ISA). PIB backgrounder. http://www.pib. nic.in/newsite/backgrounders.aspx?relid=135761.

PIB. (2016c, April 23). International Solar Alliance cell and UNDP declared cooperation for promoting solar energy. Press Release. http://pib.nic.in/newsite/PrintRele ase.aspx? relid=141095. 
PIB. (2016d, June 30). International Solar Alliance cell and World Bank signs declaration for promoting solar energy. Press Release. http://pib.nic.in/newsite/PrintR elease .aspx? relid $=146680$.

PIB. (2016e, January 25). International Solar Alliance will be the first international and inter-governmental organisation of 121 countries to have headquarters in India with United Nations as strategic partner. Press Release. http://pib.nic.in/newsite/ PrintRelease. aspx? relid=135794.

PIB. (2016f, April 23). Shri Piyush Goyal jointly launches programmes under ISA along with Ms. Ségolène Royal, French Minister of Environment \& President of COP21. Press Release. http://pib.nic.in/newsite/PrintRelease. aspx?relid=140090.

Schlager, E., \& Ostrom, E. (1992). Property-rights regimes and natural resources: A conceptual analysis. Land Economics, 1992(68), 249-262.

Solar Guidelines. (2016). Solar Guidelines. http://www.solarguidelines.in.

Terrawatt Initiative. (2016). Terrawatt Initiative. http://www.theterrawattinitiativ e.org.

United Nations. (2015). Report of the High-level Independent Panel on Peace Operations on uniting our strengths for peace: Politics, partnership and people (A/70/95-S/2015/466). https://www.un.org/en/ga/search/view_doc. asp? symbol=S $/ 2015 / 446$.

WHO Rabies Modelling Consortium. (2019). The potential impact of provision of rabies postexposure prophylaxis in Gavi-eligible countries: A modelling study. Lancet Infect Dis, 19(1), 102-111.

Open Access This chapter is licensed under the terms of the Creative Commons Attribution 4.0 International License (http://creativecommons.org/licenses/by/4.0/), which permits use, sharing, adaptation, distribution and reproduction in any medium or format, as long as you give appropriate credit to the original author(s) and the source, provide a link to the Creative Commons license and indicate if changes were made.

The images or other third party material in this chapter are included in the chapter's Creative Commons license, unless indicated otherwise in a credit line to the material. If material is not included in the chapter's Creative Commons license and your intended use is not permitted by statutory regulation or exceeds the permitted use, you will need to obtain permission directly from the copyright holder.

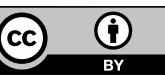

